\title{
THE STUDY ON MOVEMENTS OF THE EUSTACHIAN TUBE WITH THE SERIALOTOSALPINGOGRAPHY
}

\author{
By \\ E. YAMAGUCHI \\ From the Department of Oto-Rhino-Laryngology, School of Medicine \\ Keio University (Director: Prof. Dr. T. Nishihata)
}

By using the serial otosalpingographic apparatus, the attitude of the eustachian tube in relation to the deglutition movement was observed.

The materials were 15 patients with the perforation of the drum membrane. Patients were ordered to swallow once during infusing $40 \%$ moljodol throuth the perforation. Eight $x-r a y$ photographes were taken within $6 \mathrm{sec}$. in each cases. Twelve cases among them were successfully investigated.

The results were as follows.

1) The movement of the eustachian tube and its surrounding area in deglutition had 3 stadium; primary, maximum, and final.

2) The pharyngeal orifice and the cartilaginous area opened at almost the same time. (The primary stadinm)

3) When the deglutition movement was proceeding, the tubal cartilage moved postero-superiomedially, and pharyngeal cavity became narrow by the constraction of $\mathrm{M}$. levator veli palatini "and Mm. constrictores pharyngis. (The maximum stadium)

4) When the deglutition movement almost finished the $x$-ray findings showed similar condition to the primary stadium. (The final stadium)

5) The X-ray photograph sometimes showed two parts separated by the prominence of $M$. levator veli palatini.

6) In the case of tubal stenosis the eustachian tube enlarged during swallowing.

\section{耳管連続撮影法（Serial Otosalpingography）による

$$
\text { 耳管運動に関する研究 }
$$

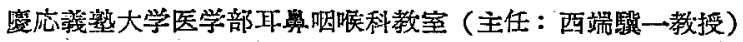

$$
\text { 助手山品, 英 明 }
$$

\section{緒 言}

1563 年 Bartholomeo Eustachio が始めて耳管につ いて記載して以来, 耳管の解剖，生理，病理，治療等に ついて相次いで多くの蕜續が発表されてきたところが 耳管は解剖的に持異な位置に存在するために直接の锤察 が困検で，ただ耳管咽頭開口部のみが直接観察できるに すぎないので耳管の開閉運動機能についての矿究は持 に制約されている。
耳管の開閍機能についての従来の交献を調へると耳管 筇の働きを 1）組織的検索を行つて推定する.2)重咽

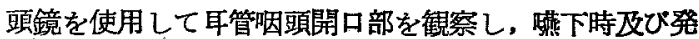
声時に，いかにその部が動くかを知つてそれより推察す る.3）耳管筋の筇電図をとつて直接調べる４）奥咽腔 に与克られた音㸷が，燕下時に耳管腔を通つて中耳腔に いかに伝達されるかを知る・5)造影成を使用して，安 静時及び䋳下時の耳管の形をレ線撮影を行つて捉える. 
等各種の方法によつて解明しようとてている.そして一 般に耳管は静止時には，両粘膜面が接して閉鎖の状態に

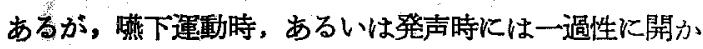
れるものであるとされている。

そして更に耳管を開く運動は耳管能（主なるのは M. tensor veli palatini, M. levator veli palatini, $M$. salpingopharyngeus 等) によつて行わ视（主に働く のは M. tensor veli palatini であるとする説と, M. levator veli palatini との協同作用によるとする説， あるいは M. levator が主に働くのであるとする説）が ある・耳管を閉鎖する働きは耳管周囲の軟部組織の䇣張 正迫，拉よび耳管軟骨の弾方性によつてなされるといわ れている.

しかしながらこの開閉運動が行われるとき，耳管は どんな形を呈するものであるか，あるいは耳管の炎症、 ポリープ, 異物, 狭窄, 開放状態等各檑の耳管疾患の場 合に，耳管腔がどんな形態をとるかは，X線的にのみ 始めて観察しらるものであり，そこにレ線撮影の診炘的 価値が存在する.

耳管の X 線撮影についての報告は，未だ甚だ少い。 我が国に和いては鈴木，北江氏等によつて耳管撮影法 (Otosalpingographia，と命名され，先に発表され， またその臨床的観察が報告されたのをみるにすぎない。

しかし今までの X 線撮影の報告はすへてて藏下時にた だ一回の撮影を行らのみであるので，圂热下運動時の耳管 膑の一瞬の变化しか知りえない，私はこの点に着目し， 連続撮影装置を使用して，蕜下運動時の耳管およびその 周囲の形態的变化を，連続的に，動的に観察しようと試 み，それに成功した・私はこの方法を連続撮影法（Serial Otosalpingography) 之命名し，得られた2,3の 知見をこつに報告する。

\section{文献的考察}

X 線による耳管の観察は Portmann, Georges, Retrouvey et Lachapele (1923)が蒾床用アマルガん を咽頭開口部より耳管に注入し耳管撮影を゙和こなつたの に始る・この方法では峡部までの撮影しかできなかつた ので，彼は更に水銀を咽頭口より注入し，去の㸶頭口を アマルガムで充填，閉塞することによつて始めて耳管全 長の撮影に成功した.そして骨部目管は軟督部耳管より も観察し難く，新生巟では耳管は成人に比してより水平 位に近いことを見出した。

又 Reverchon et Worms (1923〜1925) は造影剂々 して Lipiodol を始めて用い，生体で梌亘を扣こなつた。
粘膜は麻䣲されれば全く無痛, 無害で, 耳管の病的過程 牧よび異物を X 線的に研究するに役古つたとのべ，そ の際3つの異つた撮影法, 即ち 1) schräge Profilstellung. 2) Basisstellung (Hirtz).3) schräge Sagittalstellung (Lannois, Arcelin)の3洼を示した.

その後 1927 年には Spielberg が iodized oil を用い て撮影を执こない，耳管の長さは $3.0 \sim 3.3 \mathrm{~cm}$ ，鼓室口は 㸶頭口ょbも2 2.5crn 高く, 又肯部耳管は全長の $1 / 3$,

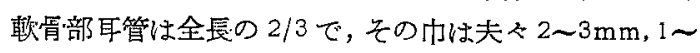
$1.5 \mathrm{~cm}$ であることをみとめ jodized oil は2〜3 分間耳 管内に留つているのみであるが，開放性耳管あるいは上 皮方菜篗している暘合は，1週間も留つていることがあ るとのべている。

次いで Heimendinger (1938)は iodized oil では長 時間耳管仢に保って和くことができないので，絧，ゴ ム，蒼鉛刜でつくつたブジーを挿入しして撮影を扎こな い，耳管の通過度および閉塞を娭索した・しかしこの方 法では耳管内腔つ正確な像がえられるとは思われない。

また Rees Jones et Mc, Gibbon (1941) は航空中 耳症で難聴をとるなつた 34 名の患者に造影滆を注入し てX線撮影を行い，狭㢳は主として軟骨部の中央に存 在することをみとめた。

さらに Welin. S. (1947) は中耳炎のある患者30 例に 10 40\%の Iodipin を用い耳管撮影を行い, 9例に病 的変化，すなわち狭渲，ポリープ，炎症性变化を示すに 成功したという、をた彼は耳管軟骨部では，Sharpな 線と,ぼやけた帯状の影像と，2種類の像が観察され， 峽部ではこれらは1つになつているとのべている。この 所見について, Gunnar K, son Aschan (1952) は sharp な線柱安全管であり，ぼやけた帯状の像はその下 部の裂目状の耳管膑を示すむのであらうとした.

Reynaud (1949) は管撮影炕患者を仰卧位とし， 頭部え䀣垂位にして Hirtz 氏方向に撮影を特こならこ とがるつともよいと提昌し，さらに狭窄を示した症例に ついて鮮明な写真を示している。

わが国に泾いては，鈴木，北师等 (1953) が Reynaud の方法に修正をくわ充，Reynaud 氏変法として耳管鉛 直位法のさらに優秀なることを㓑告した。すなわち頭部 を慜垂位とした上で，さらに頭部を左または右に，㮢查 側方向に $45^{\circ}$ 延悎させ頭頂願方向 (Vertikomentale Aufnahme) に撮影を行らのである。そしてこの方法で の詳䍃な臨床恠告がなされている。

これらの珯文献は甲管の X 線撮影の歴史であるが， 
いまだはなはだ末翡拓の分野であると思われる、耳管つ 長さ，巾，狭窄部等 X 線による耳管の形態についての 派告はみられるが，解剖例をらることがきわめて困難で あるためか，体系つけられたものとはなつていない.ま して與下運動を行らとき耳管の内腟およびその周囲がい かに变化してゆくかに至つては全く不明のままとなつて いる・しかしこの不明の点も, 庶下時にたた一枚の影像 だげでなく，さらに多くの影像が得られ耳管の運動を遑 続的に，動的に観察できるようにするならば，容易に解 明されるものと思われる.耳管の運動をこの連統撮影法 で観察した派告は外匡交献にもいまだ見当らなく全く 最初の試みである・私はここにこの報告の意羙を見出 し，本研究をすするた。

\section{観 察 対 象}

昭和 29 年 1 月より，29 年 10 月にいたる期間に，庭 大:耳㒻和诸室を訪れた慢性化膿性中耳炎患者つうち，特 に鼓莫穿孔の大なるものをえらび，15 例に撮影を行い， その内 12 例に成切した。

\section{撮 影 方 法}

1) 乎技：太口の $5 \mathrm{cc}$ の注射器にポリッェル氏ゴム 球の先を接合する・これを外耳道に密着させ，40\%モル ヨドールを少しづつ圧入し，この間に碵下運動を反復さ せる・咽頭にモルョドールが流下したのを感知したなら

\section{第 1 図}

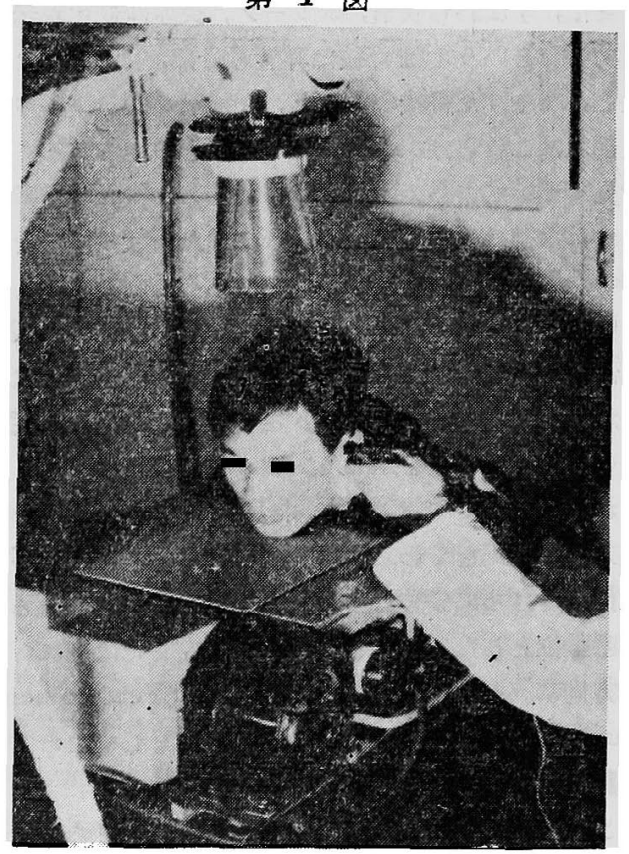

第 2 图

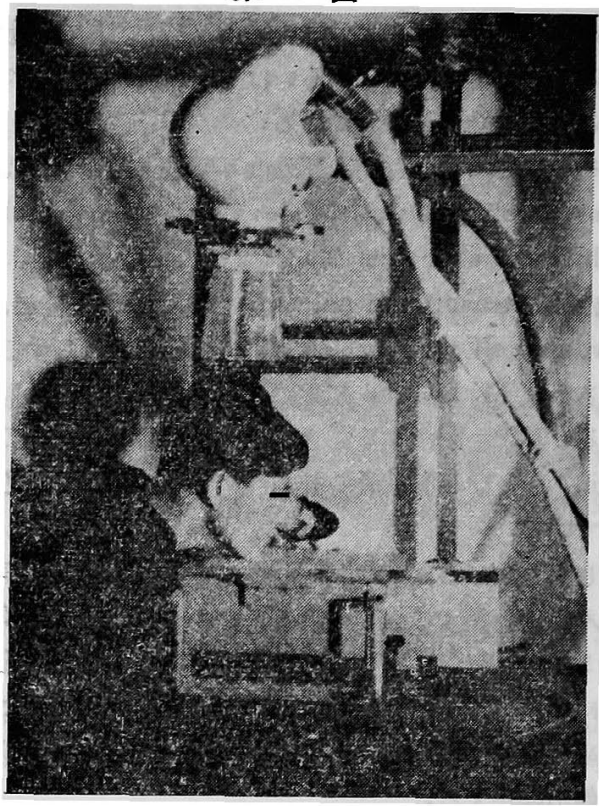

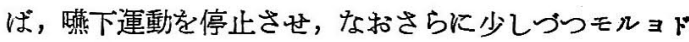
一ルを压入しながら，次にのべる連続撮影装置を迴転さ せる・この装置の廷転の間に 1 回だけ燕下運動を行わせ て，この影像を追求した・撮影方向は，さきに鈴木，北 川等によつて Reynaud 氏変法と名づけられた耳管鉊直 位法によつた・すなわち，患者を仰臥位となし，頭部を 䫘垂位に下け゚た上で，さらに碩部を左または右に，検查 側方向に $45^{\circ}$ 迴転させ, 頭頂頣方向に撮影 (Vertikomentale Aufnahme) を和こなつた（第1図，第2図）。

2）撮影装置：今回用いた連続撮影装置は慶大医学 部放射線利加藤俊男博士つ考案によるるのである，その 概略总次にのベる（第3図）。この連続撮影装置の性能 は，12 枚まで撮影が 可能で，その撮影時間は 0・7〜3.0 秒の間で適当に調節できるようになつている。

内部構造は第 3 図に示す通りであるが，少しく説明を 加えてみたい.

この装置は大きく分けて第了罒の左半分（図3a）と， 右半分（図 3b）との 2 部分に分けられる.

先づ左半分について説明すると, この部分の装置は, 一言で申せばモーターの動力をある一定時間だけ㗢かせ て，右半分で行われる撮影のための動力を提供する。

モーターのスイッテを入れ，押ボタンスイッチを押す と電磁石 $\mathrm{B}$ が動いて，接点 $\mathrm{B}_{2}$ がつく. $\mathrm{B}_{1}$ は矢印方 向に動いて 2 枚のタラッチ C 板が密着し，モーターの 
第 3 図连続撮影裝置
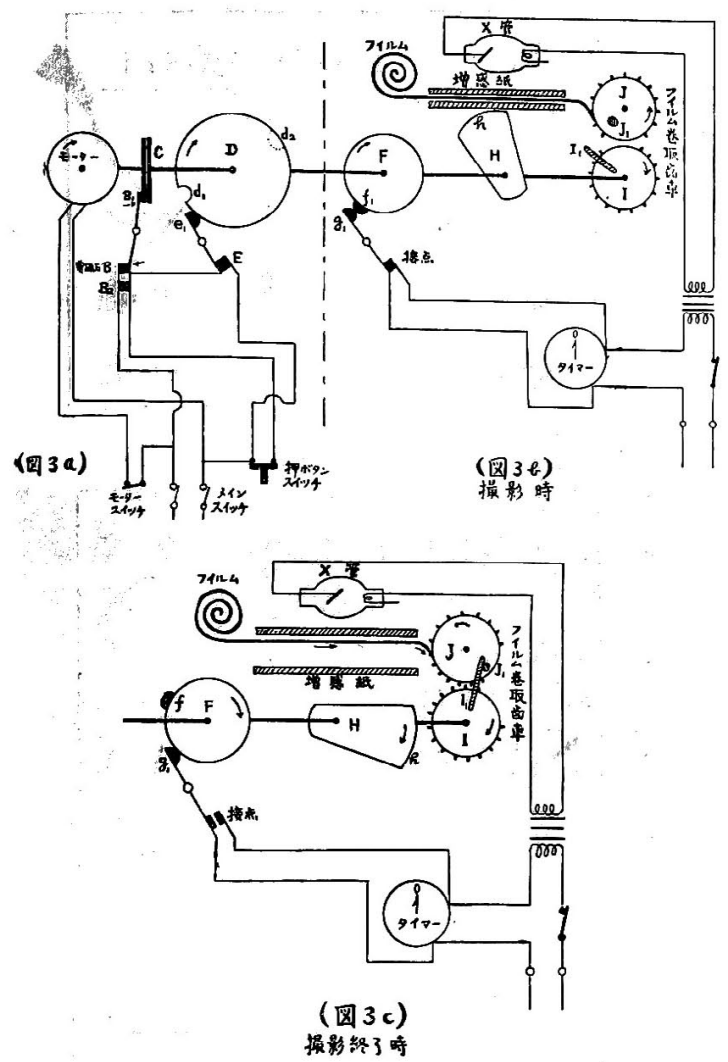

䛜転は $\mathrm{D}$ 板以下に伝えられる. $\mathrm{D}$ 板には $\mathrm{e}_{1}$ の先之同 じ型の妇れ込及 $d_{1}$ がある. $e_{1}$ が $d_{1}$ に入り込んでいる と接点 $\mathrm{E}$ がはなれ， D 板の廻転によつて $\mathrm{e}_{1}$ が $\mathrm{d}_{1}$ か ら離れると，接点 $\mathrm{E}$ は接触する。そして D 板が廷転 し始めたところで押ボタンスイッチを切る・この時は接 点 $\mathrm{E}$ は接しているので， $\mathrm{D}$ 板が廻転して $\mathrm{d}_{1}$ に $\mathrm{e}_{1}$ が 入り込むまで D 板はまわつている・しかし $\mathrm{d}_{\mathrm{i}}$ と同じ 沺及 $\mathrm{d}_{2}$ を D 板のある部に 新たに設けると, $\mathrm{d}_{1}$ から $\mathrm{d}_{2}$ までの巨離によつて 撮影枚数を加減することができ る. 即ち D 板を半迴転で止めれば，次にのべる F の 迴転回数は $1 / 2$ となり，撮影枚数も $1 / 2$ 亿減ずる.

㳄に右半分（図 3b) の機構について説明する.この 装置では $\mathrm{D}$ 板が 1 迴転する間に $\mathrm{F}$ は 12 迴転（撮影枚 擞 12 枚)するようになつている. 即ち D 板が半迴転 して $\mathrm{d}_{2}$ で止るようにすれば， $\mathrm{F}$ は6 迴転（撮影枚数 6 枚）するよらになつている・次に $F$ には $\mathrm{f}_{1}$ なる突出 部があり $\mathrm{f}_{1}$ K $\mathrm{g}_{1}$ が接している間だけ $\mathrm{X}$ 線は放射さ れるので， 巾に大小のある数個の $f_{1}$ を用意し，これを
つけかえることによりて撮影時間は自由に変更すること ができる.撮影時の図は図 $3 \mathrm{~b}$ の如くで，カム $(\mathrm{H})$ が 廻転して h の部分が増感紙を押し上げている間は，2枚 の巻取歯車は㕮合せず（歯車に料のない部分を設けてあ る) フィルムは2枚の増感紙つ間で密掅され，その間に $\mathrm{f}_{1}, \mathrm{~g}_{1}$, が接して撮影が行われる. 刃撮影が終了すると 図 $3 c$ の如く $f_{1}, g_{1}$ は離れ，カ厶 $H$ は下方に延流 し，下方の増感紙も特さえがなくなつて下方に下る。

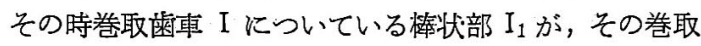
蒾車 $\mathrm{J}$ の棒状部 $\mathrm{J}_{1}$ に接し， $\mathrm{J}_{1}$ が $\mathrm{I}_{1}$ におされれる I と J の歯車は咬及合つて延転を始める. そしてフィシ ムは夈のある部分の長さだけ巻取られる・この時 $\mathrm{f}_{1}, \mathrm{~g}_{1}$

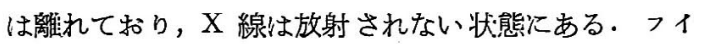
ルムが 1 枚だけ巻取られ巻取荘車が晈合しなくなると， カム $\mathrm{H}$ が增感紙を押し上げ, フィルムを密着させ, 同 時に $\mathrm{f}_{1}, \mathrm{~g}_{1}$ が接してX 線が放射される.

以上の働きが綝返されて，連続的に撮影が行われる仕 組である.な拈撮影間隔は 0.8 秒 2.0 秒をでモーター とクラッテ C の間で調節される。

3）撮影条件：上記の装置に 8 枚連続の（8つ切大）

\section{第 4 図}

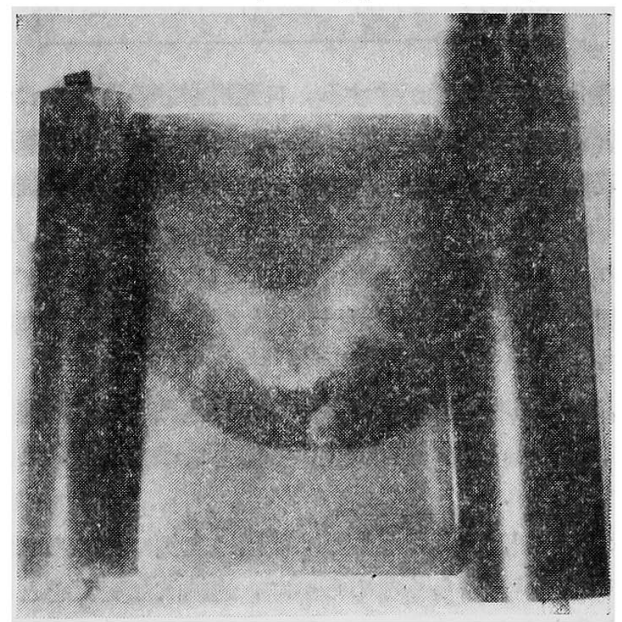

耳管模型図

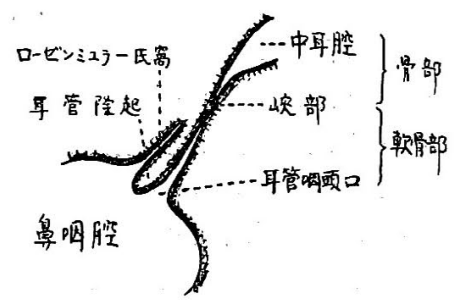


ロールフイルム（第 4 図）を㧴入し，6秒間に 8 回の撮 影を行うように調節した。そして 3 枚目より舆下運動を 1 回だけ行わせた。

\section{観察成樍及び考按}

㠮下運動に上る耳管及びその周囲の影像の形熊的変化 は，一般に3段階に分けることができる。

第1例（第 5 図）に示すように，ます欌下運動を初め ると，口蓋饮張筋と挙筋との共同作用（主として張筋で あろらが）によつて，耳管の軟骨部と耳管咽頭口はひら いて太くなる(模型図)、われわれの観察では耳管軟骨 部の開く時斯之，耳管咽頭口の開く時期とは汪とんど同 時であつて区別できなかつた・これが前期である。

第 5 図

为例 生 0 昭O 今 $26 t$

さらに瞣下運動がすすみ，口蓋邨挙筋の収縮によつて 耳管軟娟が後上内方へ押上げられたり，また咽頭收縮筋 の収維により咽頭腔が高度にせまくなると，耳管隆起及 び耳管咽頭壁 (Plica salpingopharyngea) の後方,つ まり Rosenmüller 氏简の下部に流入したモルョドール は咽頭腔中央に向つて押出されてくるこれが極斯で ある。

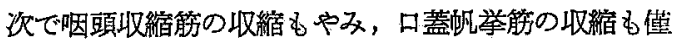
かになると，再び前期に近い影像となつてくる。これが 後期である.

この前期, 極期, 後期の 3 段階は全例仁認められた所 見であるが，恐らくなめらかに，連続的な変化をとるも のと考古られる. しかし一般に，前期之後期は短く，後 期はこれらよりる永く続いている様であるまた㶓下運 動が終了した後の耳管の太さが，この写真では耳管咽頭 口附近も，耳管軟骨部も，又ローゼンシニラー氏雟の太 さもすへてて舆下前よりも太いことが示されている。これ は恐らく粘䅕度のたかいモルョドールのために，その排 泄が困難なためであるうと考えられる。

第 2 例第 1 例と注添同樣の如見を呈している（第 6
第 6 図

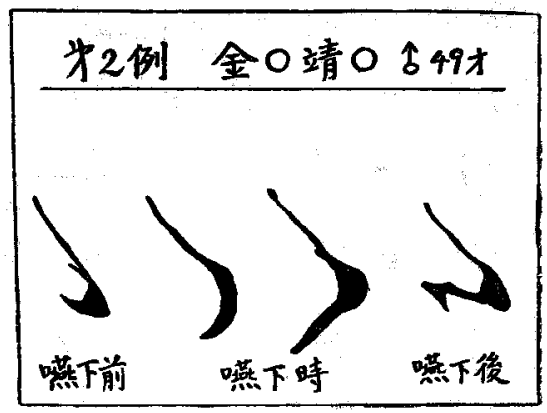

第 7 図

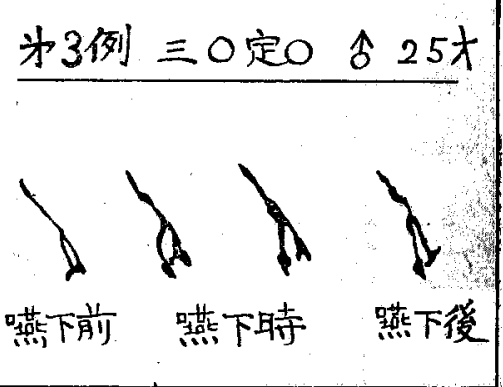

第 8 図

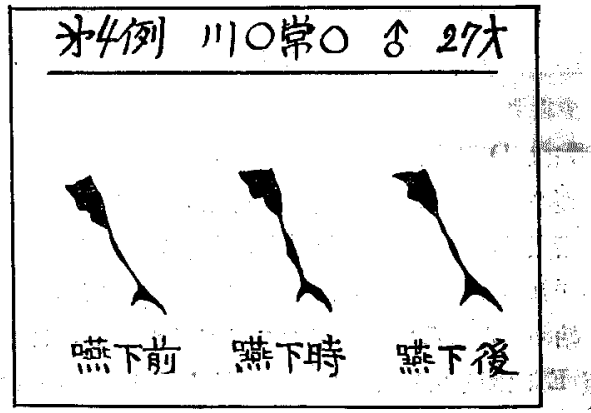

図).

第3 例（第 7 図）は第 1 例，第 2 例之異つた持異な影 像を示している・即ち耳管咽頭口において，その影像は 2つに分岐し，䁩下前と比へてその分岐中はより広くな

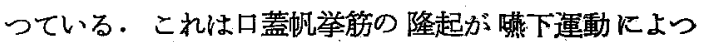
て，よ口高度となるためと考光られる・文耳管そのすの

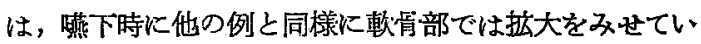
る.

第 4 例（第 8 図）では，高度の年管狭窄症を合併して いる患者で，通気圧は $35 \mathrm{~mm}$ 水銀柱を示してをり，影

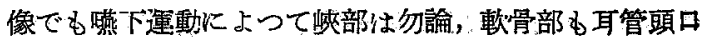




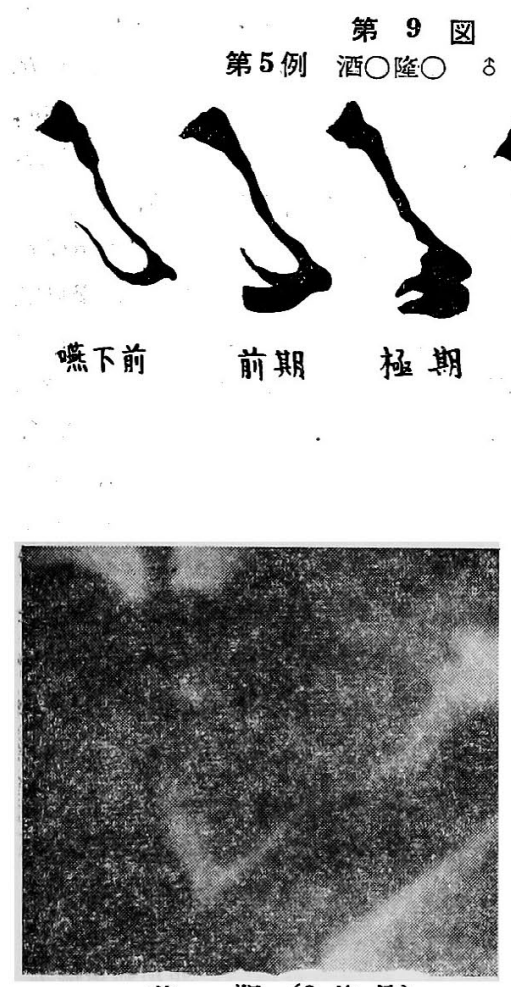

首期 (3 枚目)

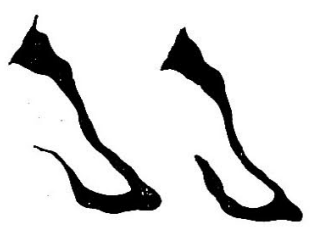

後斯嘫下後

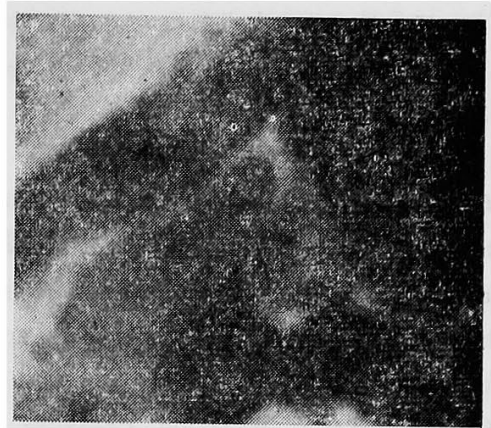

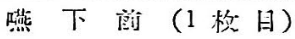

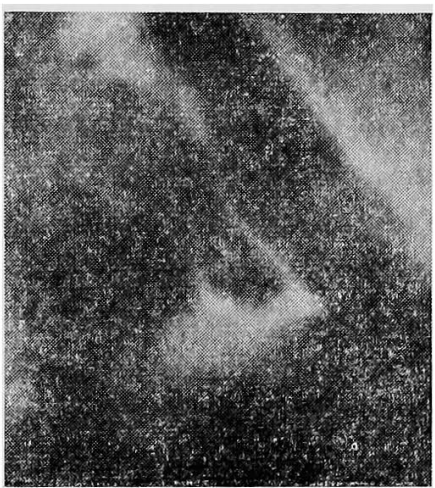

後期 (5 枚目)

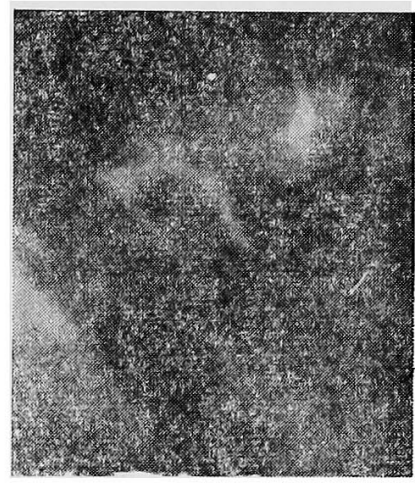

嶼下後 (8 枚目)

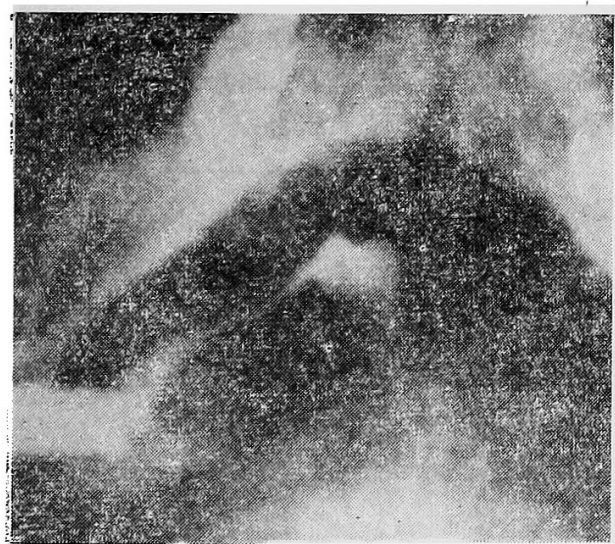

極期 (4 枚 目)

極く軽度に拡大するにすぎない，即ら䯩度の耳管狭窄 症に叔いては嚥下渾動を行つても，耳管はごく僅かに開 大するにすぎないのであろらと思われる・

第 5 例(第 9 図）は，第 1 例，第 2 例之注洼同じ所見 であるが，極期に於て耳管軟骨の後上内方への動きが幾 分悪い影像を示している.これは，埴下運動の極期の最 も高度の動きを示寸時期に撮影が行われなかつたための
もので，前期と極期の間で，さらにもら1枚の撮影がな されれば，第 1 例のごとき極期の像をしめすことができ たと考えられる。

結語

慶大放射線科加藤俊男博士の考案された迢続撮影装置 をもらいて，耳管の連続撮影を扣こない，つぎの結果を えた・

1）造影剂として 40\%モルョドール5cc を用いた。

2）鼓膜穿孔のある慢性中耳炎患者 15 例におこない， 12 例に成功した。

3）啨下運動による耳管扎よびその周团の影像の変化 は，一般に前期，極期，後期の3 段階にわけられる。

4）耳管咽頭口と軟青部耳管の開く時期は同じです る (前期).

5)さらに與下運動がすすむと， 口盖帆挙筋の収縮に よつて耳管軟穼は後上内方へおし上げられ，又咽頭収縮

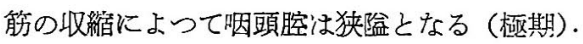

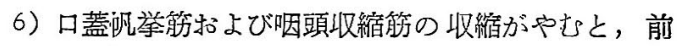
斯に近い影像にもどる(後期).

7）耳管咽頭口において，口圔帆挙筇の隆起のため影 
像方２つに分䝵することもある。

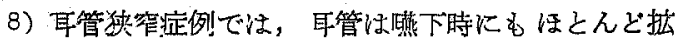
大しなからた。

\section{文 献}

(1) Gunar; K. son Aschan: Observation on the Eustachian Tube. Acta Societatis Medicorum Upsaliensis. 57 : 1.13, 1952.

(2) Heimendinger:

Ernest: Etude radiographique de la trompe d'eustach - Rev. d'otol. etc, 58: 303-310, 1938.

Mc Gibbon, JE.G.: Aviation Pressure Deafness. J. Laryng. \& Otol. 57:14(Jan) 1942 . (4) Por. tmann, Georges, Retrouvey et Lachapele: Etude radiographique de la trompe d'Eustache. Rev. de laryngol, d' otol. et de rhinol. 44(20): 849.854, 1923. (5) Portmann, Giorges, Retrouvey et Lachopéle: Etude radiographique de la trompe $\mathrm{a}^{\prime}$ Eustache. Congrés francais d'oto rhiro laryngologic, Paris, 7-9. V. 1923. (6) Rees Jones and McGibbon: Radiological Vizualisation of the Eus:achian tube. Lancet 2, 1941. (7) Reverchon et Worms: La radiographie en otorhino-Laryngolgie (Sinus et mastoide). Congr. franc. d'oto-rhinolaryngol. Paris, 7-9. V. 1923. (8) Reverchon, L. et G. Worms: L'exploration-radiologique en lipiodol en oto-rhino-laryngologie. Rev. de laryngol., d'otol. et de rhinol. 46(6): 189-193, 1925.

(9) Reynaud: L'exploration radiologique de la trompe d'Eustache. cit. par Terracol (14). (10) Spielberg, William: Visualization of the eusta- chian tube by the Roentgen ray. Arch. of Otolaryngol. $5(4)$ : 334-340, 1927.

(11) Stachy $R$. Guild: Elastic tissue of the Eustachian tube. Ann. of Oto. etc. $54(2): 537,1955$. (12) Suzuki et al. 耳管撮影法に就て，耳悬咽喉科，25 卷， 9 号, 425 429. 1933, 炤 $28 . \quad$ (12a) Y. Suzuki et

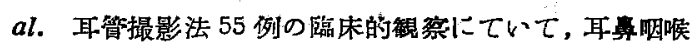
科，管 31 卷，管 2 号, 88〜92, 1959. 沿 34.

Takahara: 耳管の生理並問理，耳鼻咽喉科，24 卷， 13 묵, 642 649, 1952, 昭 27. (14) Terracol, J.: La Trompe d'Eustache (Masson) 122-128, 1949. Paris. (15) Welin, S.: On the radiological examination of the Eustachian tube in cases of chronic otitis. Acta radiologica, Stockholm. 28(1): 95-103, 1947. (16) Zöllner: Anatomie, Phyisologie, Pathologie und Klinik der Ohrtrompete u.s.w., 213. 1942.

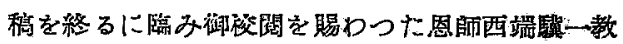

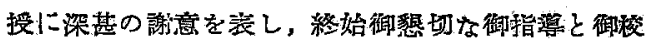

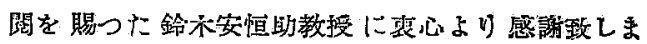

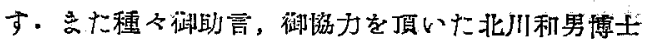

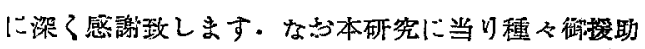
を頂いた本大学放射繶科・の各位に感謝します。

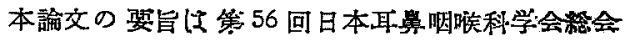
に゙むけ発紊した。

（原稿到着＝㗱和 33.11.22. 日） 